\title{
PERAN DAYA TARIK KONTEN, KEMUDAHAN PENGGUNAAN DAN KUALITAS INTERAKSI LAYANAN DALAM MENINGKATKAN PEMBELIAN DARING DI E- COMMERCE BLIBLI.COM DI PURWAKARTA
}

\author{
Oleh : \\ Indra Maulana \\ Program Studi Manajemen - STIE DR KHEZ MUTTAQIEN \\ indra.maulana1177@gmail.com \\ Rr Putri Suryaningwulan \\ Program Studi Manajemen - STIE DR KHEZ MUTTAQIEN \\ hi.putrie@yahoo.co.id \\ DOI Artikel : https://doi.org/10.34308/eqien.v7i1.117
}

\begin{abstract}
Article Info
Article History :

Received 10 Feb - 2020

Accepted $20 \mathrm{Feb}-2020$

Available Online $28 \mathrm{Feb}$ -

2020
\end{abstract}

\begin{abstract}
This study aims to obtain an overview of the implementation of content attractiveness, ease of use, quality of service interactions, online purchasing decisions, also to determine the effect of these variables both partially and jointly. Data collection uses purposive sampling technique by distributing questionnaires to 100 respondents who are e-commerce users of blibli.com in Purwakarta. The research data were then analyzed using SPSS 24. In general the implementation of content appeal, ease of use, quality of service interaction, online purchasing decisions at e-commerce blibli.com in Purwakarta has been going well. The results showed that partially, the three independent variables namely Content Attractiveness, Ease of Use and Service Interaction Quality had a positive and significant effect on Online Purchasing Decisions, where Service Interaction Quality had the most influence. And the entire Independent variable influences together (simultaneously) on Online Purchasing Decisions.
\end{abstract}

Keyword :

Content Attractiveness, Ease of

Use, Service Interaction

Quality, Online Purchasing

Decisions 


\section{PENDAHULUAN}

Saat ini minat masyarakat terhadap belanja daring semakin meningkat. Hal ini disebabkan transaksi jual beli yang sebelumnya mengharuskan adanya pertemuan langsung antara penjual dan pembeli, kini bisa dilakukan tanpa perlu adanya pertemuan langsung dengan cara memanfaatkan media daring (Phillipus dalam Reynor, 2017). Belanja daring dinggap lebih praktis karena transaksi dapat dilakukan dimana saja dan kapan saja selama ada akses internet.

Meningkatnya minat masyarakat terhadap belanja daring juga berdampak pada perkembangan industri perdagangan elektronik (e-commerce) di Indonesia. Hal ini dapat dilihat dari semakin bertambahnya jumlah e-commerce yang ada di Indonesia. Hingga tahun 2018, tercatat total $320 e$ commerce yang telah menjadi member Asosiasi E-Commerce Indonesia (idEA) (idea.or.id, diakses 16 Januari 2019). Ecommerce merupakan proses dimana pembeli dan penjual melakukan kegiatan berupa pertukaran informasi, uang dan barang/jasa melalui sarana elektronik, terutama internet (Peter dan Olson, 2014).

Jumlah e-commerce yang semakin bertambah dari tahun ke tahun membuat persaingan bisnis di industri tersebut semakin ketat. Hal ini membuat para pelaku bisnis $e$ commerce terus berusaha melakukan inovasi untuk memenuhi kebutuhan konsumen. Hal yang paling menentukan berjalan baik atau tidaknya transaksi bisnis berbasis $e$ commerce adalah keputusan pembelian konsumen secara daring (online) (Efrilia, 2016).

Salah satu yang memicu ketertarikan konsumen untuk melakukan belanja daring adalah tingkat kemenarikan konten yang disampaikan. Maka penting bagi perusahaan untuk menciptakan konten yang dapat memicu ketertarikan masyarakat untuk menggunakan e-commerce tersebut ketika akan melakukan pembelian daring. Konten yang menarik tidak hanya memberikan informasi kepada konsumen untuk membantu memutuskan membeli sebuah produk, namun juga turut meningkatkan nilai lebih pada penggunaan produk tersebut, dan memberikan hiburan tanpa mengesampingkan pencapaian tujuan perusahan melalui cara promosi yang tidak mencolok (Heidi Cohen dalam Puspitasari, Tresnati, Oktini, 2017).

Berbeda dengan membeli di toko fisik, dalam pembelian daring melalui $e$ commerce, konsumen tidak dihadapkan langsung dengan penjual, namun transaksi dilakukan melalui sebuah platform. Maka penting bagi perusahaan untuk membuat platform (baik situs maupun aplikasi) $e$ commerce yang mudah digunakan dan user friendly, karena banyak konsumen yang memilih melakukan belanja daring untuk proses yang lebih cepat dan mudah. Kemudahan penggunaan menjadi penting karena jika platform memiliki fitur yang rumit, interface yang membingungkan, atau akses yang sulit, maka akan membuat konsumen kehilangan minat untuk melakukan pembelian di e-commerce tersebut (Gustriansyah, Antony, Putra, 2015).

Selain kemudahan penggunaan, hal lainnya yang tidak kalah penting adalah kualitas interaksi layanan yang diberikan. Tidak adanya pertemuan langsung dengan penjual, membuat konsumen seringkali merasa kesulitan untuk langsung mendapat jawaban atas sesuatu yang tidak mereka mengerti ketika berinteraksi dengan situs maupun aplikasi e-commerce. Semakin sulit mereka mendapat tanggapan atas pertanyaan, semakin surut minat mereka untuk membeli (Onggo. 2005). Interaksi layanan juga mencakup bagaimana sebuah situs/aplikasi dapat memberikan rasa aman ketika konsumen akan melakukan transaksi (Alhasanah, Kertahadi, Riyadi, 2014). Selain itu, konsumen daring juga umumnya lebih menyukai adanya interaksi layanan berupa komunikasi dua arah dengan vendor $e$ commerce yang bersangkutan, sehingga jika terjadi masalah dengan pembelian, mereka akan lebih mudah melaporkannya (Hastuti, 2013). 


\section{KERANGKA PEMIKIRAN DAN PENGEMBANGAN HIPOTESIS Daya Tarik Konten}

Hermawan Kartajaya dkk (dalam Saputra, 2018:17) mendefinisikan konten sebagai "what to offer", yaitu apa yang ditawarkan kepada pelanggan. Konten merujuk pada nilai (value) apa yang ditawarkan oleh perusahaan kepada pelanggan, yang membedakan perusahaan tersebut dengan perusahaan sejenis. Witold Świeczak (2012:133) mendefinisikan konten sebagai apa yang ingin dibaca, dipelajari, dilihat, atau dialami oleh pengguna. Dari perspektif bisnis, konten adalah informasi penting yang disajikan di website, dalam aplikasi, atau melalui saluran lain dengan presentasi digital, yang memiliki misi untuk berkomunikasi.

Berdasarkan kedua definisi diatas, konten dapat diartikan sebagai nilai (value) yang ingin disampaikan oleh perusahaan, yang dikemas dalam bentuk informasi berupa presentasi yang tersedia melalui berbagai media, termasuk media elektronik seperti televisi, radio maupun internet dengan tujuan untuk berkomunikasi dengan audiens.

Konten yang menarik dibuat dengan tujuan untuk dapat menarik target pasar serta mendorong mereka untuk menjadi customer suatu perusahaan. Douglas Karr (2016) mengidentifikasi empat dimensi yang diperlukan dalam sebuah konten yaitu reader cognition, sharing motivation, persuasion, dan decision making.

\section{Kemudahan Penggunaan}

Fred Davis (dalam Efrilia, 2016) mendefinisikan kemudahan penggunaan sebagai persepsi seseorang bahwa penggunaan teknologi, dalam hal ini yaitu transaksi daring (online) merupakan hal yang mudah dan tidak memerlukan usaha keras dari pemakainya. Sedangkan Suyanto (dalam Alhasanah dkk, 2014) mendefinisikan kemudahan penggunaan sebagai suatu pengalaman berupa proses interaksi yang dilakukan oleh pengguna terhadap sebuah situs atau aplikasi, hingga pengguna tersebut dapat mengoperasikannya dengan cepat dan mudah.
Dari kedua definisi diatas, kemudahan penggunaan dapat diartikan sebagai kualitas atau tingkat kemudahan dalam pengoperasian suatu situs atau aplikasi melalui tampilan desain maupun fitur yang disampaikan kepada pengguna.

Constantinidas (dalam Hastuti, 2013), menjelaskan komponen atau dimensi dari kemudahan penggunaan yaitu kenyamanan, navigasi, kemudahan akses, kecepatan situs/aplikasi, dan kemudahan proses transaksi.

\section{Kualitas Interaksi Layanan}

Tjiptono (dalam Aditiya, 2017) mendefinisikan kualitas interaksi layanan sebagai usaha untuk memenuhi kebutuhan dan keinginan konsumen dengan cara penyampaian yang tepat untuk mengimbangi harapan konsumen tersebut. Sedangkan Barnes dan Vidgen (dalam Rosania, 2016) mendefinisikan kualitas interaksi layanan (service interaction quality) sebagai mutu dari interaksi pelayanan yang dialami oleh pengguna ketika mereka memasuki dan mempelajari lebih dalam sebuah situs website/aplikasi, yang berdampak pada terwujudnya bentuk kepercayaan dan empati. Kualitas interaksi layanan memiliki dua dimensi yaitu trust dan emphaty.

Berdasarkan kedua definisi diatas, maka kualitas interaksi layanan dapat diartikan sebagai mutu dari interaksi dan cara penyampaian perusahaan yang bertujuan untuk memenuhi kebutuhan dan keinginan konsumen ketika konsumen tersebut memasuki dan mempelajari suatu situs/aplikasi, dan terwujud dalam bentuk kepercayaan dan empati terhadap situs/aplikasi tersebut.

\section{Keputusan Pembelian Daring}

Schiffman dan Kanuk (2008) mendefinisikan keputusan pembelian sebagai suatu kegiatan yang dilakukan oleh individu, kelompok, maupun organisasi, dimana individu, kelompok atau organisasi tersebut memilih salah satu dari beberapa alternatif pilihan yang ada. Sedangkan Peter dan Olson (2014) mendefinisikan keputusan pembelian sebagai suatu proses terintegrasi dengan cara mengombinasikan pengetahuan untuk tujuan 
mengevaluasi dua atau lebih perilaku alternatif dan kemudian memilih satu di antaranya.

Berdasarkan kedua definisi diatas, maka keputusan pembelian dapat diartikan sebagai suatu kegiatan membeli sebuah produk melalui proses mengombinasikan pengetahuan, yang dilakukan oleh individu, kelompok, maupun organisasi dimana individu, kelompok atau organisasi tersebut memilih satu dari beberapa alternatif pilihan yang ada.

Keputusan pembelian daring merupakan segala kegiatan yang berkaitan dengan proses pengambilan keputusan

\section{METODE PENELITIAN}

Penelitian ini menggunakan metode kuantitatif dengan pendekatan deskriptif dan asosiatif. Populasi penelitian ini adalah konsumen umum yang merupakan pengguna e-commerce blibli.com di wilayah Kabupaten dan Kota Purwakarta. Pengambilan sampel menggunakan teknik purposive sampling dengan kriteria sebagai berikut:

a. Pernah menggunakan $e$ commerce blibli.com untuk melakukan pembelian (minimal 1 kali).

\section{HASIL DAN PEMBAHASAN}

\section{Hasil Penelitian}

\section{Hasil Analisis Regresi Linier Berganda}

Analisis regresi linier berganda berfungsi untuk menganalisis hubungan dan pengaruh antara Daya Tarik Konten $\left(\mathrm{X}_{1}\right)$, Kemudahan Penggunaan $\left(\mathrm{X}_{2}\right)$, dan Kualitas Interaksi Layanan $\left(\mathrm{X}_{3}\right)$ terhadap Keputusan Pembelian Daring (Y). Hasil perhitungan koefisien regresi yang dilakukan dengan menggunakan software SPSS 24 diperoleh persamaan regresi yaitu $\mathrm{Y}=7,566+0,236 \mathrm{X}_{1}$ $+0,216 X_{2}+0,322 X_{3}$

Koefisien Determinasi $\left(\mathbf{R}^{2}\right)$

Berdasarkan hasil perhitungan statistik diperoleh nilai $\mathrm{R}^{2}$ sebesar 0,574. Sehingga dapat disimpulkan bahwa Daya Tarik Konten $\left(\mathrm{X}_{1}\right)$, Kemudahan Penggunaan $\left(\mathrm{X}_{2}\right)$, dan Kualitas Interaksi Layanan $\left(\mathrm{X}_{3}\right)$ berpengaruh sebesar 57,4\% terhadap Keputusan Pembelian Daring (Y). konsumen dalam mendapatkan barang melalui jalur daring (online). Devaraj (dalam Hastuti, 2013) menjelaskan bahwa keputusan membeli secara daring dipengaruhi oleh:

a. Tingkat efisiensi dalam pencarian yaitu meliputi kecepatan waktu, kemudahan dalam penggunaan dan kemudahan dalam pencarian informasi.

b. Nilai (value) yang meliputi harga produk bersaing dan kualitas produk yang baik.

c. Interaksi yang meliputi kelengkapan informasi pada situs, keamanan transaksi, waktu tunggu (load time) dan navigasi situs.

b. Pernah melakukan pembelian di minimal satu e-commerce lain selain blibli.com.

Karena tidak diketahui secara pasti berapa banyak jumlah pengguna e-commerce blibli.com di Purwakarta, maka dalam menentukan ukuran sampel dalam penelitian ini menggunakan rumus Wibisono sehingga didapat 100 responden sebagai sampel.

Pengukuran terhadap responden pada penelitian ini menggunakan skala semantik diferensial. Metode analisis yang digunakan yaitu analisis regresi linier berganda.

sedangkan sisanya sebesar $42,6 \%$ dipengaruhi oleh variabel lain diluar penelitian ini.

\section{Hasil Uji F}

Berdasarkan hasil perhitungan statistik uji F Diperoleh nilai F hitung 43,199 $>\mathrm{F}$ tabel 3,94. Sehingga dapat disimpulkan bahwa secara bersama-sama Daya Tarik Konten $\left(X_{1}\right)$, Kemudahan Penggunaan $\left(X_{2}\right)$ dan Kualitas Interaksi Layanan $\left(X_{3}\right)$ berpengaruh signifikan terhadap Keputusan Pembelian Daring (Y).

\section{Hasil Uji t (Parsial)}

Berdasarkan hasil perhitungan statistik uji parsial, diperoleh hasil sebagai berikut:

a. Nilai siginifikansi untuk variabel Daya Tarik Konten $\left(\mathrm{X}_{1}\right)$ tehadap Keputusan Pembelian Daring (Y) menunjukan nilai $0,007<0,05$ dan nilai $t$ hitung $2,774>t$ tabel 1,988 sehingga dapat disimpulkan 
bahwa Daya Tarik Konten $\left(\mathrm{X}_{1}\right)$ secara parsial berpengaruh signifikan terhadap Keputusan Pembelian Daring (Y).

b. Nilai siginifikansi untuk variabel Kemudahan Penggunaan $\left(\mathrm{X}_{2}\right)$ tehadap Keputusan Pembelian Daring (Y) menunjukan nilai $0,001<0,05$ dan nilai t hitung 3,418 > t tabel 1,988 sehingga dapat disimpulkan bahwa Kemudahan Penggunaan $\left(\mathrm{X}_{2}\right)$ secara parsial

\section{Pembahasan}

Berdasarkan analisis statistik yang telah dilakukan, dapat diketahui bahwa daya tarik konten berpengaruh positif dan signifikan terhadap keputusan pembelian daring. Ini menunjukkan bahwa setiap peningkatan dari daya tarik konten akan turut juga meningkatkan keputusan konsumen dalam melakukan pembelian daring. Selaras dengan yang dikemukakan oleh Witold Świeczak (2012) bahwa konten yang menarik, kreatif dan menyediakan penerima dengan nilai akan mendorong konsumen untuk mengambil tindakan, yang dalam hal ini adalah keputusan pembelian daring. Temuan ini sejalan dengan dengan penelitian yang dilakukan oleh Herni Tri Hartanti (2018) bahwa dimensi-dimensi yang ada pada content marketing berpengaruh positif dan signifikan terhadap keputusan pembelian.

Hasil penelitian juga menunjukkan bahwa kemudahan penggunaan memiliki pengaruh yang positif dan signifikan terhadap keputusan pembelian daring. Artinya bahwa setiap peningkatan dari kemudahan penggunaan akan turut meningkatkan keputusan konsumen dalam melakukan pembelian daring. Sejalan dengan yang dikemukakan oleh J. Nielsen (dalam Gustriansyah, dkk, 2015) bahwa website yang memiliki tingkat kemudahan penggunaan yang tinggi berpeluang lebih besar untuk sering dikunjungi oleh pengguna, yang dalam hal ini adalah konsumen daring, sehingga akan menambah peluang konsumen untuk melakukan pembelian daring. Hasil penelitian ini didukung oleh penelitian sebelumnya yang dilakukan oleh Siti Romla berpengaruh signifikan terhadap Keputusan Pembelian Daring (Y).

c. Nilai siginifikansi untuk variabel Kualitas Interaksi Layanan $\left(\mathrm{X}_{3}\right)$ tehadap Keputusan Pembelian Daring (Y) menunjukan nilai $0,001<0,05$ dan nilai $\mathrm{t}$ hitung 3,291>t tabel 1,988 sehingga dapat disimpulkan bahwa Kualitas Interaksi Layanan $\left(\mathrm{X}_{3}\right)$ secara parsial berpengaruh signifikan terhadap Keputusan Pembelian Daring (Y).

dan Alifah Ratnawati (2018) bahwa variabel kemudahan penggunaan berpengaruh positif dan signifikan terhadap keputusan pembelian.

Hasil penelitian menunjukkan bahwa kualitas interaksi layanan mempunyai pengaruh yang positif dan signifikan terhadap keputusan pembelian daring. Hal ini menunjukkan bahwa setiap peningkatan dari kualitas interaksi layanan akan turut meningkatkan keputusan konsumen dalam melakukan pembelian daring. Selaras dengan yang dikemukakan oleh Barnes dan Vidgen (dalam Alhasanah, dkk, 2014) bahwa kualitas interaksi layanan adalah variabel paling penting pada penawaran e-commerce, dimana semakin baik kualitas interaksi layanan suatu website maka semakin tinggi pula keputusan pembelian online. Disamping itu, variabel kualitas interaksi layanan memiliki nilai signifikasi yang paling tinggi dibandingkan dua variabel independen sebelumnya. Temuan ini mendukung hasil penelitian sebelumnya yang dilakukan oleh Jihan Ulya Alhasanah, dkk (2014) bahwa variabel kualitas interaksi layanan adalah variabel yang paling dominan berpengaruh positif dan signifikan terhadap keputusan pembelian online.

Hasil statistik menunjukkan bahwa secara bersama-sama (simultan) variabel daya tarik konten, kemudahan penggunaan dan kualitas interaksi layanan berpengaruh positif dan signifikan terhadap keputusan pembelian daring. Berdasarkan hasil tersebut, maka dapat dilihat bahwa variabel daya tarik konten, kemudahan penggunaan dan kualitas interaksi layanan memiliki kontribusi terhadap keputusan konsumen dalam 
melakukan pembelian daring. Hal ini menunjukkan jika perusahaan e-commerce memberi perhatian lebih pada ketiga variabel tersebut dalam strategi pemasarannya, maka

\section{KESIMPULAN DAN SARAN}

Kesimpulan

Berdasarkan hasil penelitian ini, dapat disimpulkan bahwa:

1. Persepsi konsumen terhadap daya tarik konten, tingkat kemudahan penggunaan dan kualitas interaksi layanan yang dimiliki oleh e-commerce blibli sudah dapat dikategorikan baik.

2. Berdasarkan hasil uji t, diperoleh hasil bahwa daya tarik konten, kemudahan

\section{Saran}

Adapun saran yang diberikan kepada perusahaan, yaitu:

1. Diharapkan untuk blibli.com agar membuat kontennya lebih menarik lagi. Beberapa hal yang bisa dilakukan misalnya dengan membuat konten iklan yang unik dan mudah diingat oleh masyarakat, membuat konten yang bermanfaat/bersifat edukatif, mengaitkan konten dengan sesuatu yang sedang tren/viral kemudian memasarkannya melalui media sosial, atau membuat konten khusus semisal kuis/games pada situs/aplikasi sebagai tahap awal agar meningkatkan minat masyarakat untuk mengunjungi situs/mengunduh aplikasi blibli.com.

2. Diharapkan bagi blibli.com untuk meningkatkan kecepatan waktu tunggu

\section{REFERENSI}

Ahmad Aditiya. 2017. Analisis Pengaruh Kualitas Website Terhadap Kepuasan Pengguna Berdasarkan Metode Webqual 4.0 Pada Website www.wingscorp.com. Skripsi Fakultas Teknologi dan Informatika Stikom Surabaya: tidak diterbitkan

Alhasanah, J. U. (2014). Pengaruh Kegunaan, Kualitas Informasi Dan Kualitas Interaksi Layanan Web Ecommerce Terhadap Keputusan Pembelian Online (Survei Pada akan dapat meningkatkan jumlah konsumen yang melakukan pembelian daring di situs/aplikasi e-commerce tersebut.

penggunaan dan kualitas interaksi layanan secara parsial berpengaruh positif dan signifikan terhadap keputusan pembelian daring.

3. Berdasarkan hasil uji $\mathrm{F}$, diperoleh hasil bahwa daya tarik konten, kemudahan penggunaan dan kualitas interaksi layanan secara bersama-sama (simultan) berpengaruh positif dan signifikan terhadap keputusan pembelian daring.

situsnya agar dapat mempercepat proses konsumen dalam melakukan transaksi. Selain itu, desain situs blibli.com juga dapat dibuat lebih menarik, misalnya dengan membuat tampilan situs/aplikasi yang eye-catching, juga merancang fitur yang memudahkan konsumen untuk mencari produk.

3. Diharapkan untuk blibli.com agar dapat meningkatkan kemudahan interaksi dengan cara membuat fitur yang dapat lebih memudahkan konsumen untuk berkomunikasi langsung dengan penjual produk. Selain itu diharapkan juga blibli.com dapat merekomendasikan produk-produk yang sesuai dengan preferensi dan minat konsumen, untuk lebih meningkatkan empati konsumen terhadap situs tersebut.

Konsumen Www. getscoop. com). Jurnal Administrasi Bisnis, 15(2).

Arga Aji Saputra. 2018. Strategi Diferensiasi Pada Perusahaan Jasa Pengiriman Barang (Studi deskriptif pada $J \& T$ Express Yogyakarta). Skripsi Fakultas Ilmu Sosial dan Humaniora UIN Sunan Kalijaga

Onggo, B. J. (2005). Cyber Branding Through Cyber Marketing. Elex Media Komputindo. 
Reyner, B. (2017). Profiling konsumen Ecommerce: studi pada pengguna Blibli, Lazada, Berrybenka, Zalora, Bukalapak, dan Tokopedia.

Gustriansyah, R., Antony, F., \& Putra, R. R. (2015). Dampak Variabel Usability Terhadap Keputusan Pembelian Pada Website E-Commerce B2C. Jurnal Manajemen Pemasara, II, 1-7.

Hartanti, H. T. (2018). PENGARUH DIMENSI-DIMENSI CONTENT MARKETING TERHADAP KEPUTUSAN PEMBELIAN KONSUMEN (STUDI PADA AKUN INSTAGRAM@ GIGIEATCAKE) (Doctoral dissertation, Universitas Bakrie).

Hastuti, I. K. (2013). Pengaruh Faktorfaktor Fungsional, Psikologi Dan Konten Terhadap Keputusan Pembelian Produk E-commerce Website Groupon. MIX: Jurnal Ilmiah Manajemen, 3(3), 155463.

Karr, D. (2016). How to Map Your Content to Unpredictable Customer Journeys. San Francisco: Meltwater.

Karr, D. (2016). How to Map Your Content to Unpredictable Customer Journeys. San Francisco: Meltwater.

Karr, D. (2016). How to Map Your Content to Unpredictable Customer Journeys. San Francisco: Meltwater.
Romla, S., \& Ratnawati, A. (2018). KEPUTUSAN PEMBELIAN ECOMMERCE MELALUI KEMUDAHAN PENGGUNAAN, KUALITAS INFORMASI DAN KUALITAS INTERAKSI LAYANAN WEB. Jurnal Ekonomi dan Bisnis, 19(1), 59-70.

Yasir, Y., \& Rosania, R. (2016). Pengaruh Kegunaan, Kualitas Informasi dan Kualitas Interaksi Layanan Website Perpustakaan Universitas Riau terhadap Kepuasan Pengguna (Studi pada Mahasiswa Universitas Riau dengan Menggunakan Metode Webqual 4.0) (Doctoral dissertation, Riau University).

Schiffman, L., \& Kanuk, L. L. (2008). Perilaku konsumen edisi 7. Indeks, Jakarta.

Efrilia, S. Pengaruh Kemudahan Penggunaan E-Commerce terhadap Keputusan Pembelian Online (Studi pada Konsumen Tokopedia. com di Kota Medan).

Świeczak, W. (2012). Content marketing as an important element of marketing strategy of scientific institutions. Prace Instytutu Lotnictwa, 133-150.

www.idea.or.id. Asosiasi E-Commerce Indonesia. Direktori Member. Diakses 1 Januari

2019 